\title{
Effects of adding illegal storeys to structural systems
}

\author{
S KAHRAMAN*, A SAATCI and S MISIR \\ Civil Engineering Department, Faculty of Engineering, Dokuz Eylül University, \\ İzmir, Turkiye \\ e-mail: serap.kahraman@deu.edu.tr
}

MS received 20 July 2005; revised 16 November 2005

\begin{abstract}
Earthquakes in Turkey are frequently occurring disasters, causing much loss of life and property. It is tragic indeed that earthquakes should share the agenda with amnesty laws for illegal buildings. Illegal buildings are those constructed without authorization, legal bureaucratic sanction and, in most cases, without normal engineering control and checks. Buildings may become illegal for a variety of reasons. The very prospect of a waiver bill for illegal buildings spurs further illegal construction. The status of illegal buildings may legally change in time. What is an illegal building today may well be legal tomorrow under these circumstances.

The present study deals with two different kinds of building: one is the framed building and the other has shear-wall frame. The capacity ratios, storey drifts and natural periods for the legally approved buildings and the effects of illegal or legal additional floors on these values are compared. It is determined that these buildings with illegal storeys should be strengthened and retrofitted by providing cast in-situ reinforced concrete shear walls.
\end{abstract}

Keywords. Amnesty laws for illegal buildings; seismic retrofitting; storey drifts; column capacity ratios.

\section{Introduction}

A series of amnesty laws for illegal buildings (and all unauthorized construction) is always on the agenda of Turkey. Illegal buildings are various and numerous and their legal status may change with time, with the result that an illegal building today may well be legalised tomorrow. Each new waiver bill makes some more illegal buildings legal. Time is therefore of the essence. The changed situation here does not affect the structural nature of the building, but only its legal conformity and acceptance. Therefore "illegal building" as a term should be discussed. An illegal building may be built without acquiring the land rights in a suburb or it may be a luxurious building in an elegant district (Kahraman \& Misir 2004).

For instance, a building may even be illegal from the viewpoint of its location. This also may vary: the building might be built on someone else's land, on land belonging to the State,

*For correspondence 
in a river valley or in an area affected by landslides. Buildings that have been constructed in river valleys or landslide areas, in particular, are not safe from natural disasters. Problems that are probable when illegal buildings are legalized via a building waiver bill, comprise an interdisciplinary subject and call for further study.

Apart for the above mentioned buildings, there are buildings which have no project basis, i.e. are not based on formal design calculations and drawings, or buildings which have not been constructed in accordance with their project calculations, if any, and those which contain more floors than are shown in the original project etc. It is possible to enlarge the scope and content of the term illegal building.

It is disappointing and surprising that despite the fact that experts (engineers, architects, earth scientists, city planners, social scientists etc.) outlined the measures that needed to be taken after the disastrous major earthquake in Turkey in August 1999, which caused the death of tens of thousands of people, in addition to huge economical losses and considerable ill effects on society, few of them were seriously implemented by the authorities. This is not something which normally happens or should happen in a country with frequent earthquakes.

\section{Methodology}

This study deals only with one facet of a vast topic. Here, for typical structures, the capacity ratios, storey drifts and natural periods of a legal building are calculated and the effects of illegal and legal additional floors on these values are examined and compared (TS498 1997; TS500 2000; Computers \& Structures 2000).

It is assumed that the buildings were built according to the original proposal. However, it is obvious that this is not usually the case. Most optimistically, even if it is presumed that a building is built according to the original project and code, it is known that the reinforcing steel used may often be of substandard quality.

Even if the material conforms to standards, and construction is well monitored, buildings may not be able to support additional floors. The most innocent addition to a building, even a terrace, affects the dynamic behaviour of the building and changes its torsional irregularities. In locations where settlement tendency exists, where the soil is cohesive and groundwater level is high, additional floors might also cause geotechnical problems.

In this paper, two types of building: one with frame $(\mathrm{F})$ and the other with shear-wall frame (SWF) are chosen (figures 1a and b). It is assumed that these buildings are situated in the most severe earthquake zone, the ground is soft and has deep alluvial layers with a high water table. The effective ground acceleration coefficient, $A_{0}$, is assumed to be 0.4 . The same grid plan is used in all of the floors, and the columns are assigned to the axis passing through their centroids (Turkish Earthquake Specification 1998).

The concrete used is $\mathrm{C} 20$ whose cylindrical compressive strength is $20 \mathrm{MPa}$, and the building steel used is S420 whose characteristic yield strength is $420 \mathrm{MPa}$. On each of the two building models, the columns are taken as $45 \times 45 \mathrm{~cm}$ in dimension and reinforced with 16 longitudinal bars which are $16 \mathrm{~mm}$ in diameter along the axis D. Other columns are of $40 \times 40 \mathrm{~cm}$ dimension and reinforced with 12 longitudinal bars of the same diameter. The beams are $25 \times 50 \mathrm{~cm}$ in dimension, floor slabs are $14 \mathrm{~cm}$ in thickness, and each storey is $3.0 \mathrm{~m}$ in height. The shear-walls are $25 \times 200 \mathrm{~cm}$ in dimension and reinforced with 44 longitudinal bars which are $16 \mathrm{~mm}$ in diameter. After the calculations have been performed for these 4-storey buildings (4-Sb), the analyses below are conducted for three new additional floors: 

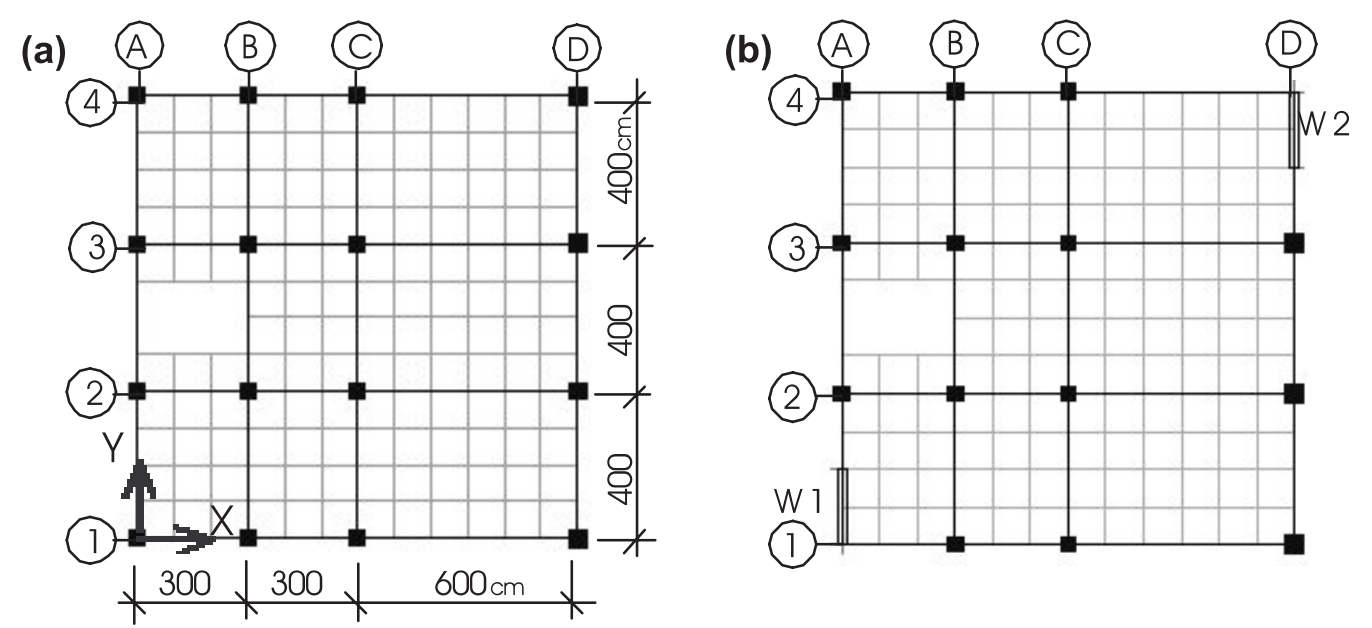

Figure 1. The plan of an F building (a) and of an SWF building (b).

- Addition of a terrace dwelling covering part of the plan (t-f) (figure 2)

- Additional complete storey (5-sb)

- Two additional complete storeys (6-sb)

To find the most critical loading, the following types of load combinations are taken into consideration:

- $1.4 \mathrm{D}+1.6 \mathrm{~L}$,

- 1.0 D $+1.0 \mathrm{~L}+1.0 \mathrm{E}_{x}$ ( $\pm \% 5$ additional eccentricities),

- $1.0 \mathrm{D}+1.0 \mathrm{~L}+1.0 \mathrm{E}_{y}$ ( $\pm \% 5$ additional eccentricities),

where $\mathrm{D}$ and $\mathrm{L}$ stand for Dead and Live Load respectively, and $\mathrm{E}_{x}$ and $\mathrm{E}_{y}$ symbolize the effects obtained from response spectrum analysis in both directions. In seismic analysis, the

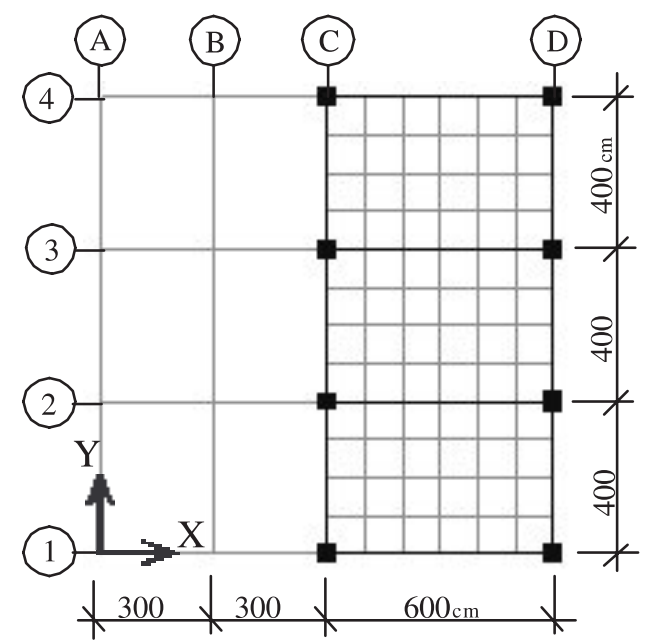

Figure 2. Terrace floor of F and SWF buildings. 


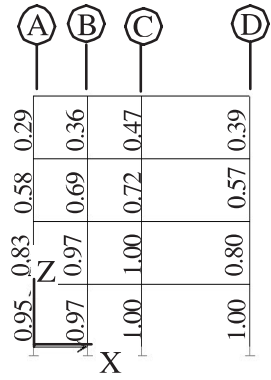

(a)

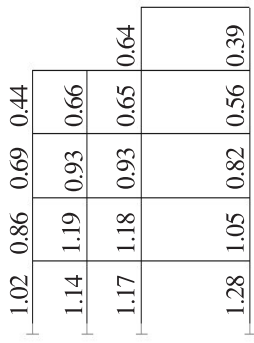

(b)

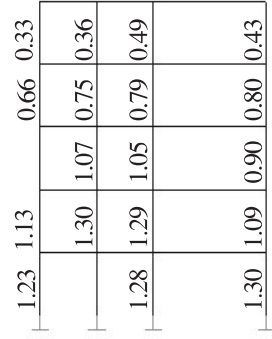

(c)

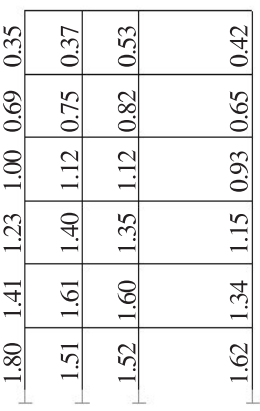

(d)

Figure 3. The column capacity ratios for axis 2-2 of F buildings: (a) 4-storey, (b) 4-storey with terrace floor, (c) 5-storey, (d) 6-storey building.

mode superposition method is used and $\pm 5 \%$ additional eccentricities are also taken into account in the calculations carried out by the building analysis and design software ETABS v7.19 (Chopra 1995; Wilson 1998; ETABS 2000, 2001).

\section{Results}

In this study, comparisons between the original and the illegal storey-added buildings are made by the column capacity ratios which give indications of the stress condition of the column with respect to the capacity of the column. The column capacity ratios of two chosen axes perpendicular to each other, i.e. axes 2-2 and A-A, are presented in figures 3 through 6 .

The first five natural periods of $\mathrm{F}$ and SWF buildings are given in table 1, and the storey drift ratios of both building types for the direction $\mathrm{Y}$ in which the rigidities of the buildings differ more obviously from each other are presented in table 2. It is seen that the drift ratio values are nearly same in cases of a terrace and a complete storey addition. As can be

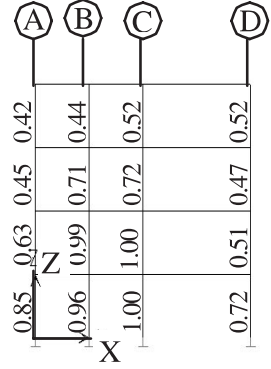

(a)

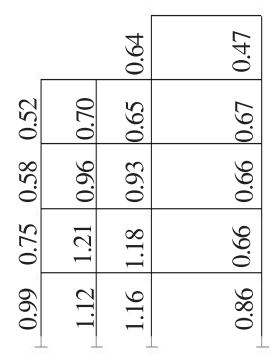

(b)

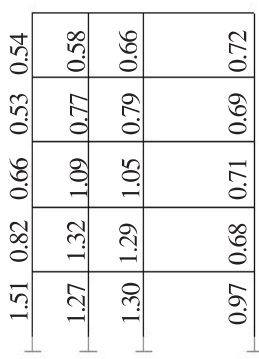

(c)

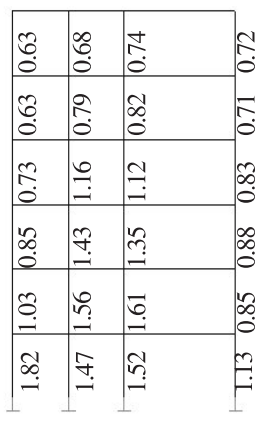

(d)

Figure 4. The column capacity ratios for axis 2-2 of SWF buildings: (a) 4-storey, (b) 4-storey with terrace floor, (c) 5-storey, (d) 6-storey building. 


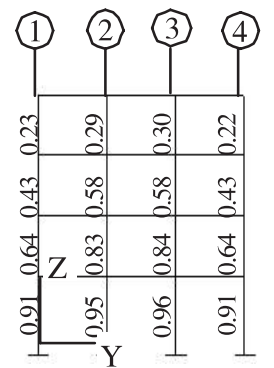

(a)

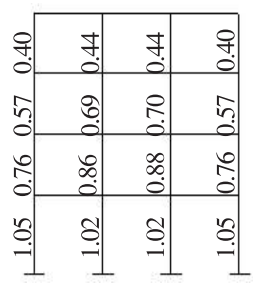

(b)

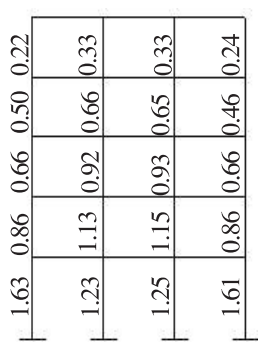

(c)

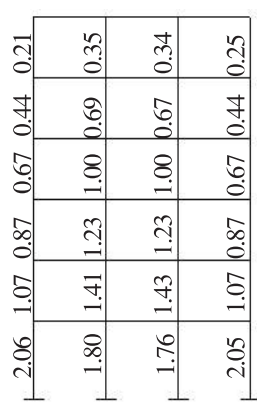

(d)

Figure 5. The column capacity ratios for axis A-A of F buildings: (a) 4-storey, (b) 4-storey with terrace floor, (c) 5-storey, (d) 6-storey building.

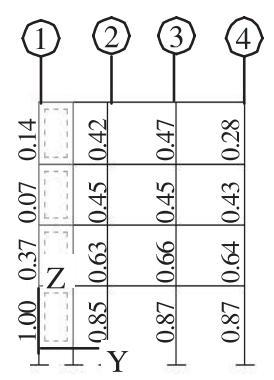

(a)

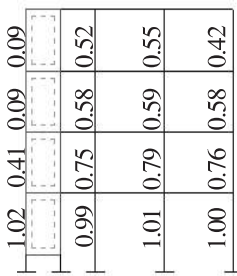

(b)

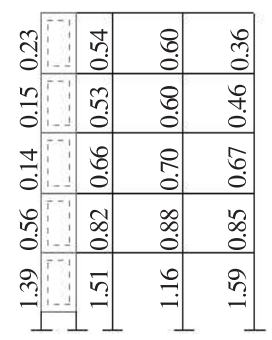

(c)

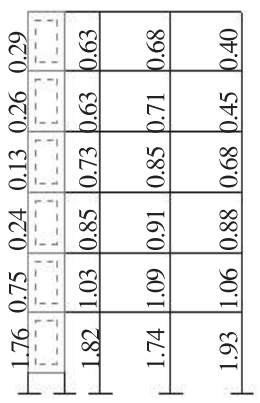

(d)

Figure 6. The column and shear-wall capacity ratios for axis A-A of SWF buildings: (a) 4-storey, (b) 4-storey with terrace floor, (c) 5-storey, (d) 6-storey building.

Table 1. Natural periods (s) of F and SWF buildings.

\begin{tabular}{|c|c|c|c|c|c|c|c|c|}
\hline \multirow{3}{*}{ Modes } & \multicolumn{8}{|c|}{ Models } \\
\hline & \multicolumn{2}{|c|}{$\begin{array}{l}\text { 4-Storey } \\
\text { building }\end{array}$} & \multicolumn{2}{|c|}{$\begin{array}{l}\text { Building with } \\
\text { terrace floor }\end{array}$} & \multicolumn{2}{|c|}{$\begin{array}{l}\text { 5-Storey } \\
\text { building }\end{array}$} & \multicolumn{2}{|c|}{$\begin{array}{l}\text { 6-Storey } \\
\text { building }\end{array}$} \\
\hline & $\mathrm{F}$ & SWF & $\mathrm{F}$ & SWF & $\mathrm{F}$ & SWF & $\mathrm{F}$ & SWF \\
\hline $1\left(u_{x}\right)$ & 0.50 & $0 \cdot 50$ & 0.59 & 0.59 & 0.63 & 0.65 & 0.77 & 0.78 \\
\hline $2\left(u_{y}\right)$ & 0.49 & $0 \cdot 38$ & 0.59 & 0.48 & 0.63 & $0 \cdot 50$ & 0.76 & 0.63 \\
\hline $3\left(\operatorname{rot}_{z}\right)$ & $0 \cdot 37$ & $0 \cdot 29$ & 0.43 & $0 \cdot 35$ & 0.47 & $0 \cdot 38$ & 0.57 & 0.48 \\
\hline $4\left(u_{x}\right)$ & $0 \cdot 16$ & $0 \cdot 16$ & $0 \cdot 20$ & $0 \cdot 20$ & $0 \cdot 21$ & $0 \cdot 21$ & $0 \cdot 25$ & $0 \cdot 25$ \\
\hline $5\left(u_{y}\right)$ & $0 \cdot 16$ & $0 \cdot 10$ & $0 \cdot 19$ & $0 \cdot 14$ & $0 \cdot 20$ & $0 \cdot 13$ & 0.25 & $0 \cdot 17$ \\
\hline
\end{tabular}


Table 2. Storey drift ratios $\left(\Delta_{\max } / h\right)$ of $\mathrm{F}$ and SWF buildings in direction $\mathrm{Y}$ for elements $D-4(\%)$.

\begin{tabular}{lcc}
\hline & \multicolumn{2}{c}{$\Delta_{\max } / h$} \\
\cline { 2 - 3 } Models & $\mathrm{F}$ & $\mathrm{SWF}$ \\
\hline 4-Storey building & $2 \cdot 6$ & $1 \cdot 5$ \\
Building with terrace floor & $3 \cdot 5$ & $2 \cdot 3$ \\
5-Storey building & $3 \cdot 6$ & $2 \cdot 3$ \\
6-Storey building & $4 \cdot 5$ & $3 \cdot 1$ \\
\hline
\end{tabular}

seen in figure 1a and table 1 , the rigidities and the consequently natural periods of $\mathrm{F}$ building are nearly the same in both directions. For an SWF building, due to two shear-walls used, the rigidity in the Y direction is considerably bigger than the other one, and therefore the natural periods for this case are smaller than those obtained for frame building, as expected.

In figures 3 and 4, it may be observed that the most critical column in axis 2-2 for internal forces is on the ground floor and situated at location A-2. The internal forces and the capacity ratios obtained for this column for framed and shear-wall frame buildings are presented in tables 3 and 4 respectively. The tables include two different values for each internal force, found under the loading corresponding to the maximum column capacity ratios (I) and the maximum ones (II). The maximum internal forces given in these tables may have been obtained for different loadings.

The internal forces and the capacity ratios obtained for column A-1 of the F buildings and shear-wall W1 of the SWF buildings are presented in tables 5 and 6 respectively, so that the behaviour differences between a column and the shear wall used instead may be seen.

Tables 7 and 8 give the relative changes in capacity ratios of all columns and shear walls in the system when new floors are added, compared to the capacity ratios of 4-storey $F$ and SWF buildings respectively. The decrease in the capacity ratios of the shear-walls in storey 4 is due to the difference in the $\mathrm{F}$ and SWF behaviour.

Table 3. Internal forces and capacity ratios for column A-2 at base floor of F building.

\begin{tabular}{|c|c|c|c|c|c|c|c|}
\hline \multirow[b]{3}{*}{ Models } & \multicolumn{2}{|c|}{$\begin{array}{l}\text { Axial force } \\
{[\mathrm{kN}]}\end{array}$} & \multicolumn{4}{|c|}{$\underset{[\mathrm{kNm}]}{\text { Bending moment }}$} & \multirow{3}{*}{$\begin{array}{l}\text { Column } \\
\text { capacity } \\
\text { ratio }\end{array}$} \\
\hline & \multirow[b]{2}{*}{ I } & \multirow[b]{2}{*}{ II } & \multicolumn{2}{|c|}{$M_{x}$} & \multicolumn{2}{|c|}{$M_{y}$} & \\
\hline & & & I & II & I & II & \\
\hline 4-Storey building & 408 & 720 & 169 & 169 & $3 \cdot 0$ & 158 & 0.95 \\
\hline Building with terrace floor & 857 & 857 & $19 \cdot 0$ & 159 & 183 & 216 & 1.02 \\
\hline 5-Storey building & 504 & 1023 & 220 & 220 & $6 \cdot 3$ & 200 & $1 \cdot 23$ \\
\hline 6-Storey building & 1283 & 1357 & $32 \cdot 4$ & 268 & 230 & 241 & $1 \cdot 80$ \\
\hline
\end{tabular}


Table 4. Internal forces and capacity ratios for column A-2 at base floor of SWF buildings.

\begin{tabular}{|c|c|c|c|c|c|c|c|}
\hline \multirow[b]{3}{*}{ Models } & \multicolumn{2}{|c|}{$\begin{array}{l}\text { Axial force } \\
{[\mathrm{kN}]}\end{array}$} & \multicolumn{4}{|c|}{$\underset{[\mathrm{kNm}]}{\text { Bending moment }}$} & \multirow{3}{*}{$\begin{array}{c}\text { Column } \\
\text { capacity } \\
\text { ratio }\end{array}$} \\
\hline & \multirow[b]{2}{*}{ I } & \multirow[b]{2}{*}{ II } & \multicolumn{2}{|r|}{$M_{x}$} & \multicolumn{2}{|c|}{$M_{y}$} & \\
\hline & & & I & II & I & II & \\
\hline 4-Storey building & 574 & 574 & $5 \cdot 7$ & 49 & 155 & 155 & $0 \cdot 85$ \\
\hline Building with terrace floor & 688 & 688 & $7 \cdot 8$ & 49 & 179 & 179 & 0.99 \\
\hline 5-Storey building & 804 & 827 & $19 \cdot 5$ & 67 & 198 & 203 & 1.51 \\
\hline 6-Storey building & 1073 & 1104 & $22 \cdot 4$ & 83 & 226 & 234 & $1 \cdot 82$ \\
\hline
\end{tabular}

Table 5. Internal forces and capacity ratios for column A-1 at base floor of F buildings.

\begin{tabular}{|c|c|c|c|c|c|c|c|c|c|}
\hline \multirow[b]{3}{*}{ Models } & \multicolumn{2}{|c|}{$\begin{array}{l}\text { Axial force } \\
{[\mathrm{kN}]}\end{array}$} & \multicolumn{2}{|c|}{$\begin{array}{c}\text { Shear force } \\
{[\mathrm{kN}]}\end{array}$} & \multicolumn{4}{|c|}{$\begin{array}{l}\text { Bending moment } \\
{[\mathrm{kNm}]}\end{array}$} & \multirow{3}{*}{$\begin{array}{c}\text { Column } \\
\text { capacity } \\
\text { ratio }\end{array}$} \\
\hline & \multirow[b]{2}{*}{ I } & \multirow[b]{2}{*}{ II } & \multirow[b]{2}{*}{ I } & \multirow[b]{2}{*}{ II } & \multicolumn{2}{|r|}{$M_{x}$} & \multicolumn{2}{|c|}{$M_{y}$} & \\
\hline & & & & & I & II & I & II & \\
\hline 4-Storey building & 565 & 565 & 89 & 89 & 11 & 153 & 165 & 165 & 0.91 \\
\hline Building with terrace floor & 679 & 679 & 103 & 103 & 13 & 153 & 192 & 192 & 1.05 \\
\hline 5-Storey building & 778 & 826 & 107 & 114 & 29 & 197 & 204 & 213 & 1.63 \\
\hline 6-Storey building & 1056 & 1121 & 129 & 136 & 34 & 238 & 247 & 257 & $2 \cdot 06$ \\
\hline
\end{tabular}

Table 6. Internal forces and capacity ratios for shear-wall W1 at base floor of SWF buildings.

\begin{tabular}{|c|c|c|c|c|c|c|c|c|c|}
\hline \multirow[b]{3}{*}{ Models } & \multicolumn{2}{|c|}{$\begin{array}{l}\text { Axial force } \\
{[\mathrm{kN}]}\end{array}$} & \multicolumn{2}{|c|}{$\begin{array}{l}\text { Shear force } \\
{[\mathrm{kN}]}\end{array}$} & \multicolumn{4}{|c|}{$\begin{array}{l}\text { Bending moment } \\
{[\mathrm{kNm}]}\end{array}$} & \multirow{3}{*}{$\begin{array}{c}\text { Shear-wall } \\
\text { column capacity } \\
\text { ratio }\end{array}$} \\
\hline & \multirow[b]{2}{*}{$\mathrm{I}$} & \multirow[b]{2}{*}{ II } & \multirow[b]{2}{*}{ I } & \multirow[b]{2}{*}{ II } & \multicolumn{2}{|c|}{$M_{x}$} & \multicolumn{2}{|r|}{$M_{y}$} & \\
\hline & & & & & I & II & I & II & \\
\hline 4-Storey building & 407 & 632 & 520 & 522 & 2362 & 2362 & 5 & 183 & 1.00 \\
\hline $\begin{array}{l}\text { Building with } \\
\text { terrace floor }\end{array}$ & 455 & 735 & 494 & 495 & 2373 & 2373 & 16 & 213 & 1.02 \\
\hline 5-Storey building & 560 & 935 & 676 & 681 & 3247 & 3253 & 12 & 242 & $1 \cdot 39$ \\
\hline 6-Storey building & 746 & 1290 & 820 & 822 & 4088 & 4088 & 17 & 280 & 1.76 \\
\hline
\end{tabular}


Table 7. The relative changes in column capacity ratios of 4-storey (with terrace floor) (t-f), 5-storey (5-sb), and 6-storey (6-sb) F buildings [\%].

\begin{tabular}{|c|c|c|c|c|c|c|c|c|c|c|c|c|}
\hline \multirow[t]{2}{*}{ Name } & \multicolumn{3}{|c|}{ Storey 1} & \multicolumn{3}{|c|}{ Storey 2} & \multicolumn{3}{|c|}{ Storey 3} & \multicolumn{3}{|c|}{ Storey 4} \\
\hline & $t-f$ & $5-s b$ & 6 -sb & $t-f$ & $5-\mathrm{sb}$ & $6-s b$ & $t-f$ & $5-s b$ & $6-s b$ & $t-f$ & $5-s b$ & $6-s b$ \\
\hline A 1 & 15 & 79 & 126 & 19 & 34 & 67 & 33 & 53 & 102 & 74 & 117 & 191 \\
\hline A2 & 7 & 29 & 89 & 4 & 36 & 70 & 19 & 59 & 112 & 52 & 128 & 245 \\
\hline A3 & 6 & 30 & 83 & 5 & 37 & 70 & 21 & 60 & 112 & 47 & 117 & 233 \\
\hline A4 & 15 & 77 & 125 & 19 & 34 & 67 & 33 & 53 & 102 & 82 & 109 & 205 \\
\hline B1 & 17 & 30 & 60 & 21 & 35 & 67 & 34 & 55 & 103 & 80 & 113 & 210 \\
\hline B2 & 18 & 27 & 56 & 23 & 34 & 66 & 35 & 55 & 103 & 83 & 108 & 211 \\
\hline B3 & 18 & 27 & 56 & 23 & 34 & 66 & 35 & 55 & 103 & 83 & 108 & 211 \\
\hline B4 & 17 & 30 & 59 & 23 & 36 & 69 & 34 & 55 & 104 & 80 & 113 & 210 \\
\hline $\mathrm{C} 1$ & 17 & 30 & 72 & 17 & 30 & 76 & 28 & 48 & 105 & 43 & 73 & 143 \\
\hline $\mathrm{C} 2$ & 17 & 28 & 52 & 18 & 29 & 60 & 29 & 46 & 88 & 38 & 68 & 138 \\
\hline C3 & 17 & 28 & 52 & 18 & 29 & 60 & 29 & 46 & 88 & 38 & 68 & 138 \\
\hline $\mathrm{C} 4$ & 17 & 30 & 72 & 16 & 29 & 76 & 28 & 47 & 107 & 35 & 73 & 143 \\
\hline D1 & 31 & 30 & 98 & 26 & 32 & 62 & 37 & 49 & 89 & 26 & 81 & 93 \\
\hline D2 & 28 & 30 & 62 & 31 & 36 & 68 & 44 & 58 & 102 & 44 & 105 & 138 \\
\hline D3 & 26 & 31 & 60 & 29 & 34 & 65 & 44 & 56 & 100 & 41 & 105 & 138 \\
\hline D4 & 26 & 30 & 107 & 26 & 38 & 74 & 35 & 32 & 74 & 43 & 75 & 71 \\
\hline
\end{tabular}

When the values in the tables are examined, it is seen that the relative increase in the column capacity ratios are larger in upper storeys. However, any chosen column dimension is the same in all storeys in both the present study and most of the buildings encountered in

Table 8. The relative changes in column and shear-wall capacity ratios of 4-storey with terrace floor (t-f), 5-storey (5-sb), and 6-storey (6-sb) SWF buildings [\%].

\begin{tabular}{|c|c|c|c|c|c|c|c|c|c|c|c|c|}
\hline \multirow[t]{2}{*}{ Name } & \multicolumn{3}{|c|}{ Storey 1} & \multicolumn{3}{|c|}{ Storey 2} & \multicolumn{3}{|c|}{ Storey 3} & \multicolumn{3}{|c|}{ Storey 4} \\
\hline & $t-f$ & $5-s b$ & 6 -sb & $t-f$ & $5-s b$ & $6-s b$ & $t-f$ & 5 -sb & $6-s b$ & $t-f$ & $5-s b$ & 6 -sb \\
\hline W1 & 2 & 39 & 76 & 11 & 51 & 103 & 29 & 100 & 243 & -36 & 0 & -7 \\
\hline A2 & 16 & 78 & 114 & 19 & 30 & 63 & 29 & 47 & 89 & 24 & 26 & 74 \\
\hline A3 & 16 & 33 & 100 & 20 & 33 & 65 & 31 & 56 & 102 & 17 & 28 & 81 \\
\hline A4 & 15 & 83 & 122 & 19 & 33 & 66 & 35 & 56 & 105 & 50 & 64 & 143 \\
\hline B1 & 18 & 34 & 59 & 22 & 35 & 69 & 34 & 57 & 105 & 72 & 98 & 193 \\
\hline B2 & 17 & 32 & 53 & 22 & 33 & 58 & 35 & 54 & 101 & 59 & 75 & 164 \\
\hline B3 & 18 & 33 & 53 & 21 & 32 & 63 & 36 & 56 & 104 & 57 & 73 & 159 \\
\hline B4 & 17 & 35 & 57 & 22 & 34 & 71 & 34 & 55 & 108 & 81 & 100 & 195 \\
\hline $\mathrm{C} 1$ & 16 & 31 & 64 & 17 & 28 & 73 & 30 & 48 & 88 & 34 & 64 & 134 \\
\hline $\mathrm{C} 2$ & 16 & 30 & 52 & 18 & 29 & 61 & 29 & 46 & 88 & 25 & 52 & 115 \\
\hline C3 & 16 & 32 & 52 & 19 & 29 & 63 & 29 & 45 & 86 & 35 & 61 & 129 \\
\hline $\mathrm{C} 4$ & 15 & 33 & 70 & 16 & 27 & 82 & 29 & 49 & 114 & 36 & 64 & 128 \\
\hline D1 & 16 & 32 & 55 & 26 & 31 & 67 & 53 & 47 & 81 & 17 & 26 & 46 \\
\hline D2 & 19 & 35 & 57 & 29 & 33 & 67 & 40 & 51 & 87 & 29 & 33 & 60 \\
\hline D3 & 20 & 38 & 59 & 29 & 34 & 68 & 36 & 52 & 88 & 11 & 0 & 20 \\
\hline W2 & 35 & 38 & 73 & 49 & 51 & 100 & 125 & 113 & 238 & -29 & -21 & 0 \\
\hline
\end{tabular}




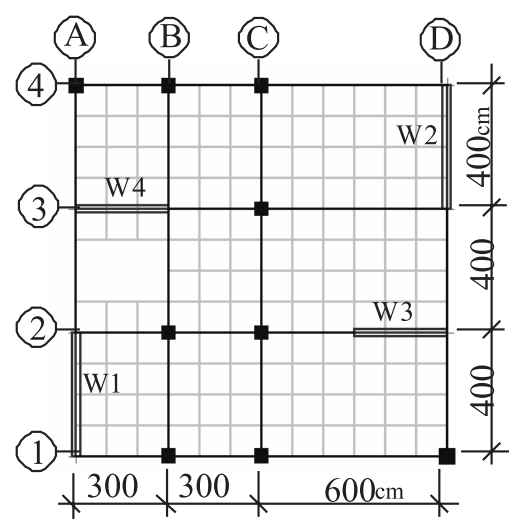

Figure 7. Plan of a retrofitted building.

practice, especially those constructed with reinforced concrete. Hence, on account of minimum section and reinforcement requirements and construction practicability, the capacity ratios of first storey columns generally exceed the critical level when illegal storeys are added. If the columns and shear-walls are designed in limit dimensions which make capacity ratios approach 1, the most critical columns will be ones in the upper storeys.

\section{Retrofitting of existing illegal storey-added buildings}

It is obvious that, when the values in the related tables are perused, in the case of addition of new floors to these buildings, the columns considered do not provide sufficient resistance. Hence, if new floors are added, in order to cope with the new internal forces which occur in the columns, column capacities should be considerably more than in the previous case. Consequently, buildings have to be strengthened to resist seismic forces (Utku \& Wasti 1997; Fardis 2003). As a method of strengthening to restore structures to at least the life-safety level, the provision of cast in-situ reinforced concrete shear walls throughout the height of the buildings in both directions is chosen. As can be seen in figure 7, a shear wall $25 \times 400 \mathrm{~cm}$ in dimension, reinforced with 84 longitudinal bars which are $16 \mathrm{~mm}$ in diameter on each of the axes $A$ and $D$ in direction $Y$, and a shear wall $25 \times 300 \mathrm{~cm}$ in dimension reinforced with 62 longitudinal bars with the same diameter on each of the axes 2 and 3 in direction $X$ are added to both types of buildings.

When the original buildings are analysed for only vertical loads, as shown in table 9, it is observed that the column capacity ratios even on the ground floor do not exceed the critical

Table 9. Capacity ratios of ground storey columns of two types of 6-storey-buildings before retrofitting for vertical load combination $(1 \cdot 4 \mathrm{D}+1 \cdot 6 \mathrm{~L})$.

\begin{tabular}{|c|c|c|c|c|c|c|c|c|}
\hline \multirow[b]{2}{*}{ Axes } & \multicolumn{4}{|c|}{ Framed building } & \multicolumn{4}{|c|}{ Shear-wall frame building } \\
\hline & A & B & $\mathrm{C}$ & $\mathrm{D}$ & A & B & $\mathrm{C}$ & $\mathrm{D}$ \\
\hline 1 & $0 \cdot 29$ & 0.39 & 0.55 & $0 \cdot 35$ & $0 \cdot 11$ & $0 \cdot 37$ & 0.55 & $0 \cdot 35$ \\
\hline 2 & 0.43 & 0.57 & 0.79 & 0.51 & $0 \cdot 31$ & 0.55 & 0.80 & 0.51 \\
\hline 3 & 0.43 & 0.57 & 0.79 & 0.51 & 0.43 & 0.57 & 0.79 & 0.41 \\
\hline 4 & 0.29 & 0.39 & 0.55 & 0.35 & 0.29 & 0.40 & 0.56 & 0.15 \\
\hline
\end{tabular}


Table 10. Natural periods ( $\mathrm{T})$ of retrofitted buildings [s] and their relative decrease with respect to unretrofitted buildings [\%].

Models

\begin{tabular}{|c|c|c|c|c|c|c|c|c|c|}
\hline \multirow[b]{2}{*}{ Modes } & \multicolumn{3}{|c|}{$\begin{array}{l}\text { Building with } \\
\text { terrace floor }\end{array}$} & \multicolumn{3}{|c|}{ 5-Storey building } & \multicolumn{3}{|c|}{ 6-Storey building } \\
\hline & $\mathrm{T}$ & $\mathrm{F}$ & SWF & $\mathrm{T}$ & $\mathrm{F}$ & SWF & $\mathrm{T}$ & $\mathrm{F}$ & SWF \\
\hline $1\left(u_{x}\right)$ & $0 \cdot 36$ & 39 & 39 & $0 \cdot 37$ & 41 & 43 & 0.47 & 39 & 40 \\
\hline $2\left(u_{y}\right)$ & $0 \cdot 29$ & 51 & 40 & $0 \cdot 31$ & 51 & 38 & 0.41 & 46 & 35 \\
\hline $3\left(\operatorname{rot}_{z}\right)$ & $0 \cdot 21$ & 51 & 40 & $0 \cdot 24$ & 49 & 37 & $0 \cdot 31$ & 46 & 35 \\
\hline $4\left(u_{x}\right)$ & $0 \cdot 13$ & 35 & 35 & 0.09 & 57 & 57 & $0 \cdot 12$ & 52 & 52 \\
\hline $5\left(u_{y}\right)$ & $0 \cdot 12$ & 37 & 14 & 0.07 & 65 & 46 & 0.09 & 64 & 47 \\
\hline
\end{tabular}

value, i.e. 1. For this reason, in the analysis of retrofitting, it was assumed that the existing buildings have not yet experienced any noticeable earthquake and therefore are undamaged. Accordingly, the mechanical characteristics of materials have been assumed to have the same values as used in the previous analyses without any reduction, especially for the concrete. Hence, to compare results, the new added shear walls have also been made using the same materials of comparable quality.

The first five natural periods and the storey drift ratios of retrofitted buildings together with their relative changes with respect to original buildings with illegal storeys are given in tables 10 and 11 respectively.

Table 12 gives the column and shear-wall capacity ratios of retrofitted buildings in case of new floor additions.

\section{Conclusions}

In the present study, effects of additional floors on buildings are investigated and the obtained column capacity ratios, natural periods and maximum storey drift ratios are compared with those of an existing 4-storey building. The comparisons indicate that the elements of 4-storey framed and shear-wall frame buildings cannot support additional floors or terraces. As the weight of the additional floor increases, the internal forces and consequently the required column capacity also increase. If the original 4-storey buildings have been designed properly

Table 11. Storey drift ratios $\left(\Delta_{\max } / \mathrm{h}\right)$ of retrofitted buildings in direction $Y$ and their relative decrease with respect to unretrofitted buildings at $X=12 \mathrm{~m}$ and $Y=12 \mathrm{~m}$.

\begin{tabular}{lccc}
\hline & & \multicolumn{2}{c}{ Relative changes [\%] } \\
\cline { 3 - 4 } Models & $\Delta_{\max } / \mathrm{h}[\%]$ & $\mathrm{F}$ & $\mathrm{SWF}$ \\
\hline Building with terrace floor & 0.92 & 74 & 60 \\
5-Storey building & 0.98 & 73 & 57 \\
6-Storey building & 1.37 & 70 & 56
\end{tabular}


Table 12. Column and shear-wall capacity ratios of retrofitted buildings.

\begin{tabular}{|c|c|c|c|c|c|c|c|c|c|c|c|c|}
\hline \multirow[b]{2}{*}{ Name } & \multicolumn{3}{|c|}{ Storey 1} & \multicolumn{3}{|c|}{ Storey 2} & \multicolumn{3}{|c|}{ Storey 3} & \multicolumn{3}{|c|}{ Storey 4} \\
\hline & $t-f$ & $5-s b$ & 6 -sb & $t-f$ & $5-s b$ & 6 -sb & $t-f$ & $5-s b$ & $6-s b$ & $t-f$ & $5-s b$ & 6-sb \\
\hline W1 & 0.49 & 0.70 & 0.90 & $0 \cdot 28$ & 0.43 & 0.58 & $0 \cdot 14$ & 0.23 & 0 & 0.05 & 0.08 & $0 \cdot 16$ \\
\hline W2 & 0.73 & 0.77 & 1.00 & 0.46 & 0.49 & 0.67 & $0 \cdot 25$ & $0 \cdot 27$ & 0.40 & 0.09 & $0 \cdot 11$ & $0 \cdot 20$ \\
\hline W3 & 0.85 & 0.76 & 0.97 & 0.45 & 0.41 & 0.55 & $0 \cdot 20$ & $0 \cdot 19$ & 0.28 & 0.06 & 0.08 & 0.14 \\
\hline W4 & $0 \cdot 87$ & 0.79 & 1.00 & 0.51 & 0.42 & 0.56 & $0 \cdot 26$ & $0 \cdot 20$ & 0.29 & $0 \cdot 10$ & 0.08 & $0 \cdot 14$ \\
\hline A4 & 0.26 & $0 \cdot 32$ & $0 \cdot 27$ & $0 \cdot 26$ & $0 \cdot 32$ & $0 \cdot 29$ & $0 \cdot 24$ & 0.28 & $0 \cdot 32$ & $0 \cdot 27$ & $0 \cdot 23$ & $0 \cdot 28$ \\
\hline B1 & 0.26 & $0 \cdot 30$ & $0 \cdot 36$ & $0 \cdot 36$ & 0.40 & 0.43 & 0.43 & 0.46 & 0.45 & 0.53 & 0.49 & 0.43 \\
\hline B2 & 0.38 & 0.44 & $0 \cdot 50$ & $0 \cdot 36$ & 0.41 & 0.48 & $0 \cdot 37$ & 0.41 & 0.46 & 0.44 & $0 \cdot 39$ & 0.43 \\
\hline B4 & $0 \cdot 28$ & $0 \cdot 31$ & $0 \cdot 38$ & $0 \cdot 37$ & $0 \cdot 38$ & 0.48 & 0.40 & 0.40 & $0 \cdot 51$ & $0 \cdot 50$ & $0 \cdot 38$ & 0.49 \\
\hline $\mathrm{C} 1$ & 0.45 & 0.43 & 0.51 & 0.48 & 0.47 & 0.43 & 0.48 & 0.48 & 0.40 & 0.46 & 0.47 & $0 \cdot 35$ \\
\hline $\mathrm{C} 2$ & 0.65 & 0.46 & 0.54 & 0.58 & 0.50 & 0.56 & 0.52 & 0.51 & 0 . & 0.45 & 0.55 & 0.75 \\
\hline $\mathrm{C} 3$ & 0.64 & 0.61 & 0.70 & 0.66 & 0.67 & 0.63 & 0.62 & 0.64 & $0 \cdot 60$ & 0.57 & $0 \cdot 61$ & 0.51 \\
\hline $\mathrm{C} 4$ & 0.43 & 0.45 & 0.54 & 0.44 & 0.49 & 0.47 & 0.42 & 0.47 & 0.48 & $0 \cdot 39$ & 0.45 & 0.44 \\
\hline D1 & $0 \cdot 31$ & 0.29 & $0 \cdot 37$ & $0 \cdot 36$ & $0 \cdot 31$ & $0 \cdot 38$ & $0 \cdot 32$ & 0.28 & $0 \cdot 35$ & $0 \cdot 30$ & 0.29 & $0 \cdot 31$ \\
\hline
\end{tabular}

by considering seismic forces, as may be seen in table 9 , these buildings can bear vertical loads in case of new floor additions. However, analysis results show that these structures may be expected to collapse even in a moderate earthquake. In an atmosphere where engineering services are not adequate, where there are distortions and arbitrariness in the implementation of existing laws and regulations, and where construction of additional storeys is retrospectively legalized by amnesty laws, the main problem is to be able to bring in urgent, realistic and practicable solutions to prevent the collapse of these types of buildings during earthquakes that might occur. The economic conditions of the inhabitants of these buildings must also be considered to suggest proper solutions and not financially overburden them.

In this paper, the provision of cast in-situ reinforced concrete shear walls throughout the height of the buildings in both directions, which is a widely used strengthening method, is chosen as an example of application. The added shear walls are designed to have approximately $1 \%$ of the base area of the structure in each direction, and it is observed that the natural periods and relative drift ratios decrease significantly while column and shear wall capacity ratios do not exceed critical values.

Medium strength earthquakes, which occur frequently in Turkey, should be considered seriously by engineers. The worst aspect of the matter is to get innured to the damage caused by such events, consider these disasters as normal and remain just onlookers. Earthquakes undoubtedly cause major problems. However, even if it is not possible to completely recover from or avoid these problems, it is possible to mitigate their effects. One of the significant measures to be taken is to stop the waiver bill to legalise such buildings, and be aware of the dangers they cause. It is necessary to develop public awareness about the subject, to provide for the active contributions of civil engineers to this process and to develop realistic policies.

\section{References}

Chopra A K 1995 Dynamics of structures: Theory and applications to earthquake engineering (Englewood Cliffs, NJ: Prentice Hall) 
Computers \& Structures 2000 ACI 318-99 adapted with TS500 building code. Computers \& Structures, Inc. http://www.comp-engineering.com/ETABManT.htm

ETABS 2000 Building analysis and design software users manual non-linear v7, Computers and Structures Inc. http://www.comp-engineering.com/ETABManT.htm

ETABS 2001 non-linear v7.19, Building analysis and design software. Computers and Structures Inc., Berkeley, CA

Fardis M N 2003 Seismic assessment and retrofitting of existing buildings according to Eurocode 8 . Invited lecture. Fifth Natl. Conf. on Earthquake Engineering, Turkish Earthquake Foundation, İstanbul, Turkey

Kahraman S, Misir S 2004 Structural effects of floors added out of project (in Turkish). Proc. 17th Technical Congress and Exhibition (İstanbul: Turkish Chamber of Civil Eng.) pp 112-114 (abstract) (full text available on $\mathrm{CD}$ )

TS498 1997 Design loads for buildings, Turkish Standards Institution, Ankara

TS500 2000 Requirements for design and construction of reinforced concrete structures, Turkish Standards Institution, Ankara

Turkish Earthquake Specification 1998 Specification for structures to be built in disaster areas. Ministry of Public Works Settlement, Government of Republic of Turkey (issued on 2.9.1997, effective from 1.1.1998, amended on 2.7.1998)

Utku M, Wasti S T 1997 In-situ strengthening of reinforced concrete buildings damaged in the Dinar earthquake. Fourth Nat. Conf. on Earthquake Engineering (Ankara: Turkish Natl. Committee for Earthquake Eng.) pp 220-229

Wilson E L 1998 Three dimensional static and dynamic analysis of structures (Berkeley, CA: Computers \& Structures) 